\title{
A Degradação das Aguas Continentais Sob a Perspectiva dos Pescadores Artesanais de Bacia de Campos
}

Mauro Macedo Campos \& Geraldo Márcio Timóteo

DOI - 10.25160/v5i2.d10

\section{Introdução}

A importância da água é inquestionável para todas as formas de vida e representa um bem comum a todas as pessoas. Os interesses que envolvem esta temática são normatizados e devem ser geridos de forma coletiva. Para tanto, há um processo de gestão que incorpora a participação popular descentralizada, amparado pela Constituição de $1988^{1}$, atribuindo à sociedade, o dever de defender os bens ambientais para as presentes e futuras gerações. Tem o mesmo ordenamento estabelecido, quatro anos mais tarde, pela Organização das Nações Unidas, na Declaração do Rio em 1992, ao considerar uma participação descentralizada, tanto no acesso às informações e "mecanismos judiciais e administrativos, inclusive no que se refere à compensação e reparação de danos" (ONU, 1992). Na formalização da política nacional de recursos hídricos, a participação popular foi garantida quase uma década depois, pela lei 9.433 de 1997, em que passou a definir uma gestão descentralizada, com a participação do poder público, dos usuários e das comunidades.

A partir deste o pano de fundo normativo, este artigo tem por objetivo analisar a essencialidade das águas, não apenas para o consumo humano, mas para as condições de trabalho e subsistência econômica das famílias de pescadores artesanais da Bacia Petrolífera de Campos, na parte do litoral norte do Estado de Rio de Janeiro, Brasil.

O ponto aqui é compreender a importância deste "fator de produção", sob a ótica de quem trabalha e depende das águas. Em especial os pescadores de águas continentais que fazem uso do sistema de bacias hidrográficas. Estes recursos são ordenados por comitês de bacia hidrográfica, que têm como norte regulatório o sistema nacional de gerenciamento de recursos hídricos, delimitados nas áreas de atuação das bacias hidrográficas, sub-bacias ou grupo de bacias ou sub-bacias hidrográficas contíguas. Este

\footnotetext{
${ }^{1}$ Ver artigo 225 da Constituição Federal de 1988, onde estabelece que todos têm direito ao meio ambiente ecologicamente equilibrado, bem de uso comum do povo e essencial a sadia qualidade de vida, impondo-se ao Poder Público e à coletividade o dever de defendê-lo e preservá-lo para as presentes e futuras gerações.
} 
sistema complexo e descentralizado, funciona com uma gestão paritária, com espaço e voz para os três segmentos da sociedade nas decisões relativas à água, inclusive no que concerne à cobrança pelo uso das águas (Totti, 2008).

No que concerne ao recorte para a elaboração deste artigo, a abordagem empírica tem como base a atuação do Programa de Educação Ambiental (PEA) Pescarte ${ }^{2}$ e os trabalhos de campo realizados por este projeto, com o apoio da Universidade Estadual do Norte Fluminense Darcy Ribeiro (UENF), localizada em Campos dos Goytacazes, principal município da Região Norte do Estado do Rio de Janeiro.

A participação da UENF é resultado de uma parceria com a Petrobras e o Instituto Brasileiro do Meio Ambiente e dos Recursos Naturais Renováveis (IBAMA). O principal objetivo do projeto é contribuir para o fortalecimento da organização dos pescadores artesanais por meio da implantação de projetos de geração de trabalho e renda. As inserções no campo foram realizadas ao longo de 24 meses de vigência do projeto, de junho de 2014 a julho de 2016,

Para o desenvolvimento deste artigo foram consideradas três abordagens empíricas realizadas pela equipe de pesquisa, sendo: 1) a fala dos pescadores e suas famílias, captadas em uma série de reuniões com os comunitários; 2) os grupos focais realizados com os pescadores e suas famílias; e 3) os dados coletados pelo questionário tipo censitário do PEA Pescarte ${ }^{3}$.

Assim, o artigo busca compreender um ponto específico, dentro da abrangência dos objetivos do projeto, que é exatamente a percepção dos pescadores artesanais acerca da degradação hídrica das áreas em que atuam. Trata-se de um estudo que busca trazer as inquietudes de quem trabalha e vive das águas, a partir de um processo em fluxo contínuo de degradação e assoreamento dos rios, lagos e lagoas e os impactos na geração de trabalho e renda destes trabalhadores. A partir dessa noção mais geral, o texto busca se cercar de dados coletados junto aos pescadores artesanais que podem ajudar no entendimento deste problema.

\footnotetext{
${ }^{2}$ O PEA Pescarte é um projeto de mitigação ambiental, e obedece aos parâmetros estabelecidos em Plano de Trabalho formulado a partir das condicionantes oriundas da Nota Técnica CGPEG/DILIC/IBAMA n 01/2010, Linha "A", e do Diagnóstico Participativo do PEA-BC. O projeto é fruto do Plano de Caracterização Regional da Bacia de Campos (PCR-BC), e tem como objetivo a execução de ações de mitigação decorrentes da exploração e produção de petróleo e gás na Bacia de Campos (BC) desenvolvida pela Petrobras, tendo como foco as comunidades de pescadores artesanais circunscritas em sete municípios da BC no estado do Rio de Janeiro.
}

${ }^{3}$ Os dados do Censo foram coletados até 31 dezembro de 2015, com início em novembro de 2014. 


\section{Características do campo e da pesquisa}

A Bacia de Campos ${ }^{4}$ é parte do litoral do Estado do Rio de Janeiro e concentra a maioria dos investimentos, estatais e privados, no segmento de exploração de petróleo e gás. Representa o maior reservatório de petróleo e gás do Brasil, correspondendo a de 67\% de toda a produção nacional de petróleo, (Petrobras; Mineral, 2015) de toda a produção offshore $^{5}$. A liderança neste ambiente empresarial cabe à Petrobras, empresa brasileira de controle estatal, que divide este espaço (geográfico e de mercado) com outras cinco grandes corporações privadas do setor petrolífero: a HRT Participações em Petróleo; a OGPar Óleo e Gás Participações; a Chevron Corporation Brasil; a Shell Brasil; e a Statoil. São compostas pela maior parte de capital estrangeiro, sendo que as duas primeiras são consórcios que contam com capital nacional.

É neste ambiente complexo e de alta competitividade econômica que estas grandes corporações convivem com as comunidades pesqueiras. Atuam distantes, nas plataformas offshore. Mas, seus impactos alcançam a todos que estão em terra. $\mathrm{O}$ adensamento populacional, oriundo da atração de milhares de pessoas em busca de uma oportunidade de emprego, leva à ocupação de áreas irregulares; a pressão sobre os recursos hídricos; e a privatização do litoral, atingem a atividade pesqueira de forma direta.

A ação estatal sobre esse processo é realizada por meio da Coordenação Geral de Petróleo e Gás (CGPEG), órgão do IBAMA, que atua no sentido de regular e controlar os Programas de Educação Ambiental, implementados na costa brasileira. E as comunidades de pescadores artesanais, por serem a comunidade reconhecidamente mais atingida pela ação das petroleiras, são sujeitos de vários projetos destas corporações empresariais. Esses projetos são considerados na categoria de mitigação socioambiental e políticas de compensação ambiental (Campos; Timóteo e Silva, 2015), regulados pela Nota Técnica 01/2010 (IBAMA, CGPEG, 2010). O que significa que eles ganham a configuração de uma política pública, pois, são considerados condicionantes de licenças ambientais. A figura 1 destaca os projetos vigentes na Bacia de Campos.

\footnotetext{
${ }^{4} \mathrm{~A}$ BC possui atualmente 55 campos de petróleo, com 826 poços exploratórios. Estes poços de petróleo estão vinculados a 45 plataformas marítimas, sendo a maioria (41 plataformas) de produção e quatro de processamento.

${ }^{5}$ As plataformas de extração de petróleo podem ser no continente, sendo denominadas de "plataforma onshore" ou no mar, que são as chamadas "plataforma offshore", possuindo uma estrutura moderna de perfuração em alto mar, abrigando trabalhadores e equipamentos necessários na perfuração de poços, além da extração de petróleo e gás. Tais plataformas podem ser fixas no solo marinho, ou flutuantes.
} 
Figura 1: Mapa dos Projetos de Educação Ambiental na Bacia de Campos

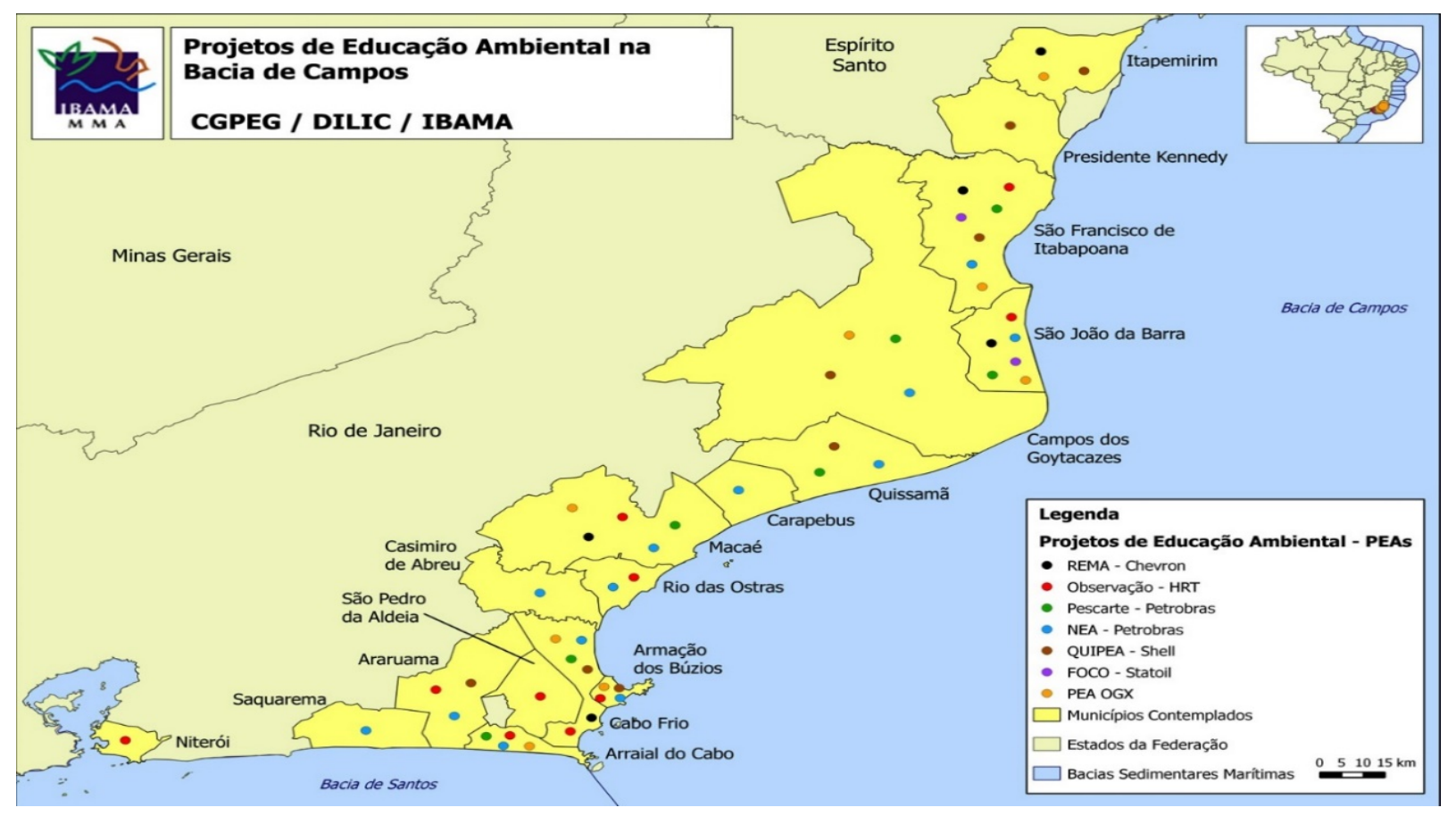

Fonte: Coordenação-Geral de Petróleo e Gás (CGPEG)/Diretoria de Licenciamento Ambiental (DILIC)/IBAMA.

É nesse ambiente que se insere o PEA Pescarte, compondo o mosaico de iniciativas de programas de educação ambiental. E sendo mais específico ainda, é a partir daí que se busca entender os impasses e problemas com gestão e manuseio das águas, como um meio de produção essencial para os pescadores artesanais e suas famílias.

$\mathrm{O}$ alcance da pesquisa e capacidade de intervenção se restringe a sete municipios da Bacia de Campos, localizados no Norte Fluminense: Arraial do Cabo, Cabo Frio, Macaé, Quissamã, Campos dos Goytacazes, São João da Barra e São Francisco de Itabapoana. Nestes municípios o PEA Pescarte tem como sujeitos de suas ações os trabalhadores envolvidos na pesca artesanal.

A pesca (marítima e de águas de interiores) representa uma atividade econômica significativa para a região. Trata-se de um setor importante para a promoção de emprego e renda nos municípios da Bacia de Campos. Este ambiente compõe o recorte espacial da pesquisa, cujos municípios foram selecionados a partir da interferência que recebem na atividade pesqueira pelos empreendimentos de petróleo e gás. Na tabela 1, são apresentados os critérios selecionados para os municípios analisados, em relação aos 
demais municípios da Bacia de Campos. Os critérios para este recorte englobam todos os pescadores. Porém, para este artigo os depoimentos foram considerados apenas os pescadores de águas de interiores.

Tabela 1: Critérios de Seleção de Municípios para o PEA-Pescarte

\begin{tabular}{l|c|c|c|c}
\hline \multicolumn{1}{c|}{ Municípios } & $\begin{array}{c}\text { Sobreposição das } \\
\text { Atividades no } \\
\text { Espaço Marinho[1] } \\
(\mathrm{em} \%)\end{array}$ & $\begin{array}{c}\text { Volume Médio de } \\
\text { Pescado } \\
\text { desembarcado por } \\
\text { mês[2] (em \%) }\end{array}$ & $\begin{array}{c}\text { Número de } \\
\text { Pescadores[3] } \\
(\mathrm{em} \%)\end{array}$ & $\begin{array}{c}\text { Contribuição da } \\
\text { pesca para a } \\
\text { Renda } \\
\text { Familiar[4] } \\
(\mathrm{em} \%)\end{array}$ \\
\hline Arraial do Cabo & 2,8 & 17,9 & 7,4 & 42,0 \\
\hline Cabo Frio & 11,9 & 40 & 12,6 & 20,0 \\
\hline Campos dos Goytacazes & 0 & 20,4 & 20,8 & 76,0 \\
\hline Macaé & 36,4 & 34,2 & 23,3 & 25,0 \\
\hline Quissamã & 0 & 16,2 & 1,5 & 48,0 \\
\hline São Francisco de & 40,6 & 24,1 & 23,3 & 68,0 \\
\hline Itabapoana & 8,4 & 35,7 & 9,1 & 27,0 \\
\hline
\end{tabular}

Fonte: PCRs - Petrobras/Projeto Pescarte, 2013.

[1] Dados do registro de avistagens das plataformas e abordagens dos navios de pesquisa sísmica dos barcos de pesca artesanal dentro da área de exclusão no período de 2007-2012 na Bacia de Campos.

[3] Dados do Ministério da Pesca e Aquicultura de 2013.

[2] Dados retirados do Relatório do Projeto de Caracterização Regional da Bacia de Campos (PCR-BC).

[4] Dados retirados do Relatório do Projeto de Caracterização Regional da Bacia de Campos (PCR-BC) considerando o número de famílias no município com renda de até $\mathrm{R} \$ 600,00$.

A tabela 2 evidencia as entrevistas em cada um dos municípios. As informações tomam por base os questionários aplicados durante o Censo PEA Pescarte realizado com os pescadores e suas famílias, em 246 localidades $^{6}$, distribuídas em 38 comunidades $^{7}$, nos sete municípios. Os dados apontam um número expressivo de respondentes, em um total de 3.478 famílias, com um total de 4.331 pescadores, perfazendo um total 10.082 membros dessas famílias.

O respondente principal (pescador ou pescadora) prestaram informações a partir de um questionário composto por 10 blocos de informações sociais ${ }^{8}$. A realização desta tarefa

\footnotetext{
${ }^{6}$ São consideradas localidades espaços em que se encontram pelo menos três famílias de pescadores.

${ }^{7}$ São consideradas comunidades aqueles espaços em que são encontradas no mínimo 33 famílias e que conte com embarque, desembarque e comercialização do pescado.

${ }^{8}$ O questionário do Censo PEA Pescarte foi composto pelos blocos: 1) Identificação Socioeconômica/Características Demográficas; 2) Bloco de Caracterização Familiar; 3) Bloco Avaliação de Serviços Públicos (habitação, energia, água,
} 
não foi nada simples. Passa antes de tudo, pela "disponibilidade" das pessoas em dispenderem um tempo razoável para responder os questionários, com média de aplicação de 2:30h. E isso não é tudo. Tem a questão da "desconfiança", aliada ao descrédito com os programas de educação ambiental que vez ou outra batem às suas portas. Portanto, trata-se de um número expressivo, sob qualquer aspecto, o que torna mais contundente os resultados da pluralidade das análises que podem ser extraídas da pesquisa.

\begin{tabular}{|c|c|c|c|c|c|}
\hline & & Frequência & Porcentual & Porcentagem válida & $\begin{array}{l}\text { Porcentagem } \\
\text { acumulativa }\end{array}$ \\
\hline \multirow{8}{*}{ Válido } & $\begin{array}{l}\text { São Francisco do } \\
\text { Itabapoana }\end{array}$ & 3.055 & 30,3 & 30,3 & 30,3 \\
\hline & Cabo Frio & 1.738 & 17,2 & 17,2 & 47,5 \\
\hline & Campos dos Goytacazes & 1.643 & 16,3 & 16,3 & 63,8 \\
\hline & São João da Barra & 1.272 & 12,6 & 12,6 & 76,5 \\
\hline & Arraial do Cabo & 1.096 & 10,9 & 10,9 & 87,3 \\
\hline & Macaé & 841 & 8,3 & 8,3 & 95,7 \\
\hline & Quissamã & 437 & 4,3 & 4,3 & 100,0 \\
\hline & Total & 10.082 & 100,0 & 100,0 & \\
\hline
\end{tabular}

Fonte: PCRs - Petrobras/Projeto Pescarte, 2014.

Já a tabela 3 faz um escrutínio relativo aos ambientes de pesca. A tabela decorre de uma pergunta do questionário sobre o local em que atuam. Como dito anteriormente, uma grande parcela deste público atua com a pesca marítima, entre os respondentes o equivalente a $55,6 \%$ (2.410 respondentes), assim identificados que realizam sua atividade em águas salgadas ou salobras, como é o caso das lagunas. Já para os pescadores de água de interiores temos $29,1 \%$ (1.264) respondentes e pescadores que exercem sua atividade nos dois ambientes, 9,1\% (393 respondentes). Somados os percentuais tem-se $38,2 \%$ que dependem do sistema de águas doce e, por sua vez, da qualidade e conservação dessas águas para o seu trabalho e sustento de suas famílias.

esgoto); 4) Bloco Avaliação de Serviços e Equipamentos Públicos (saúde, educação, assistência social, cultura, comunicação); 5) Bloco Trabalho e Trajetória Profissional; 6) Caracterização da Atividade Pesqueira; 7) Bloco Capital Social e Laços Fracos; 8) Bloco Gênero; 9) Módulo de Caracterização da Educação Ambiental na Bacia de Campos; 10) Inquérito alimentar para pescadores. 
Tabela 3: Qual é o seu ambiente de pesca?

\begin{tabular}{|c|c|c|c|c|c|c|}
\hline \multirow{2}{*}{ Municípios } & \multicolumn{5}{|c|}{ Ambiente de Pesca } & \multirow{2}{*}{ Total } \\
\hline & Interiores & Marítimo & Misto & Não respondeu & Não se aplica & \\
\hline Campos dos Goytacazes & $\begin{array}{c}438 \\
53,3 \%\end{array}$ & $\begin{array}{c}362 \\
44,1 \%\end{array}$ & $\begin{array}{c}10 \\
1,2 \%\end{array}$ & 0 & $\begin{array}{c}11 \\
1,3 \%\end{array}$ & 821 \\
\hline Macaé & $\begin{array}{c}5 \\
1,5 \% \\
\end{array}$ & $\begin{array}{c}289 \\
88,4 \% \\
\end{array}$ & $\begin{array}{c}6 \\
1,8 \% \\
\end{array}$ & $\begin{array}{c}14 \\
4,3 \% \\
\end{array}$ & $\begin{array}{c}13 \\
4 \% \\
\end{array}$ & 327 \\
\hline São Francisco do Itabapoana & $\begin{array}{c}320 \\
23,7 \% \\
\end{array}$ & $\begin{array}{c}725 \\
53,6 \% \\
\end{array}$ & $\begin{array}{c}218 \\
16,1 \% \\
\end{array}$ & $\begin{array}{c}12 \\
0,9 \% \\
\end{array}$ & $\begin{array}{c}78 \\
5,8 \% \\
\end{array}$ & 1353 \\
\hline São João da Barra & $\begin{array}{c}147 \\
27,7 \% \\
\end{array}$ & $\begin{array}{c}251 \\
47,3 \% \\
\end{array}$ & $\begin{array}{c}74 \\
13,9 \% \\
\end{array}$ & $\begin{array}{c}2 \\
0,4 \% \\
\end{array}$ & $\begin{array}{c}57 \\
10,7 \% \\
\end{array}$ & 531 \\
\hline Arraial do Cabo & $\begin{array}{c}85 \\
19,1 \% \\
\end{array}$ & $\begin{array}{c}296 \\
66,4 \% \\
\end{array}$ & $\begin{array}{c}44 \\
9,9 \% \\
\end{array}$ & $\begin{array}{c}7 \\
1,6 \% \\
\end{array}$ & $\begin{array}{c}14 \\
3,1 \% \\
\end{array}$ & 446 \\
\hline Cabo Frio & $\begin{array}{c}189 \\
28,4 \% \\
\end{array}$ & $\begin{array}{c}387 \\
58,2 \% \\
\end{array}$ & $\begin{array}{l}40 \\
6 \% \\
\end{array}$ & $\begin{array}{c}19 \\
2,9 \%\end{array}$ & $\begin{array}{c}30 \\
4,5 \%\end{array}$ & 665 \\
\hline Quissamã & $\begin{array}{c}80 \\
42,6 \% \\
\end{array}$ & $\begin{array}{c}100 \\
53,2 \% \\
\end{array}$ & $\begin{array}{c}1 \\
, 5 \% \\
\end{array}$ & $\begin{array}{c}1 \\
0,5 \% \\
\end{array}$ & $\begin{array}{c}6 \\
3,2 \% \\
\end{array}$ & 188 \\
\hline Total & $\begin{array}{c}1.264 \\
29,2 \%\end{array}$ & $\begin{array}{r}2.410 \\
55,6 \%\end{array}$ & $\begin{array}{c}393 \\
9,1 \%\end{array}$ & $\begin{array}{c}55 \\
1,3 \%\end{array}$ & $\begin{array}{c}209 \\
4,8 \%\end{array}$ & $\begin{array}{c}4331 \\
100,0 \%\end{array}$ \\
\hline
\end{tabular}

Fonte: Questionário PEA Pescarte, 2015.

A próxima seção busca descrever brevemente a composição do sistema de gestão das águas, por meio dos comitês de bacias hidrográficas. Do universo coberto pela pesquisa, como já ressaltado, este artigo se volta para os pescadores de águas interiores, que são aqueles atingidos diretamente pelos problemas decorrentes da degradação dos rios, lagos e lagoas da região Norte Fluminense.

\section{Bacias Hidrográficas e os Comitês de Bacias: os canais de participação dos municípios selecionados pelo PEA Pescarte}

O modelo brasileiro de política de implantação de recursos hídricos, via organismos de bacia, subsidiado, especialmente pelo mecanismo formal de participação, pela via dos Comitês de Bacias Hidrográficas. Este é um ponto fundamental para que se possa entender os mecanismos com os quais o Estado tornou possível a inserção da sociedade civil nas discussões sobre gestão das águas, cada vez mais entendido como um bem público, dotado de valor econômico, social e político. Ainda mais se se considera o contexto de escassez ambiental, desastres naturais, demandas de mercado e populacional (Giddens, 2010; Denhez, 2013). 
O processo de gestão institucional de recursos hídricos no Brasil foi formalizado pela lei $n^{0} 9.433$ de 1997. Esta legislação trouxe a questão da gestão descentralizada das águas, com a participação do poder público, dos usuários, com a inserção do setor privado, e da sociedade. Trata-se, portanto, de um mecanismo de intervenção institucional, que privilegia a participação social e a gestão compartilhada e integrada deste recurso.

O ordenamento jurídico traz o reconhecimento da água a partir do seu entendimento como um bem econômico e de domínio público e, com isso, incentivar a racionalização do seu uso. Neste sentido, a participação popular, se dá pelos comitês de bacia hidrográfica, que funcionam como uma espécie de "parlamento das águas", tendo na sua composição representantes da sociedade civil organizada, dos usuários e do poder público ${ }^{9}$. Estes comitês são órgãos civis que compõem o sistema nacional de gerenciamento de recursos hídricos, com uma área de atuação as bacias hidrográficas, subbacias ou grupo de bacias ou sub-bacias hidrográficas contíguas. Tem delimitação territorial definida, em função da unidade territorial. Para o que se pretende neste artigo, destacam-se os comitês de bacia hidrográfica existentes no estado do Rio de Janeiro, previamente estabelecido pelo campo de atuação do PEA Pescarte. A figura 2 e na sequência, a tabela 4 , trazem a delimitação de atuação os comitês de bacia espalhados pelo Estado, bem como as informações acerca de cada comitê

Figura 2: Regiões Hidrográficas do Estado do Rio de Janeiro

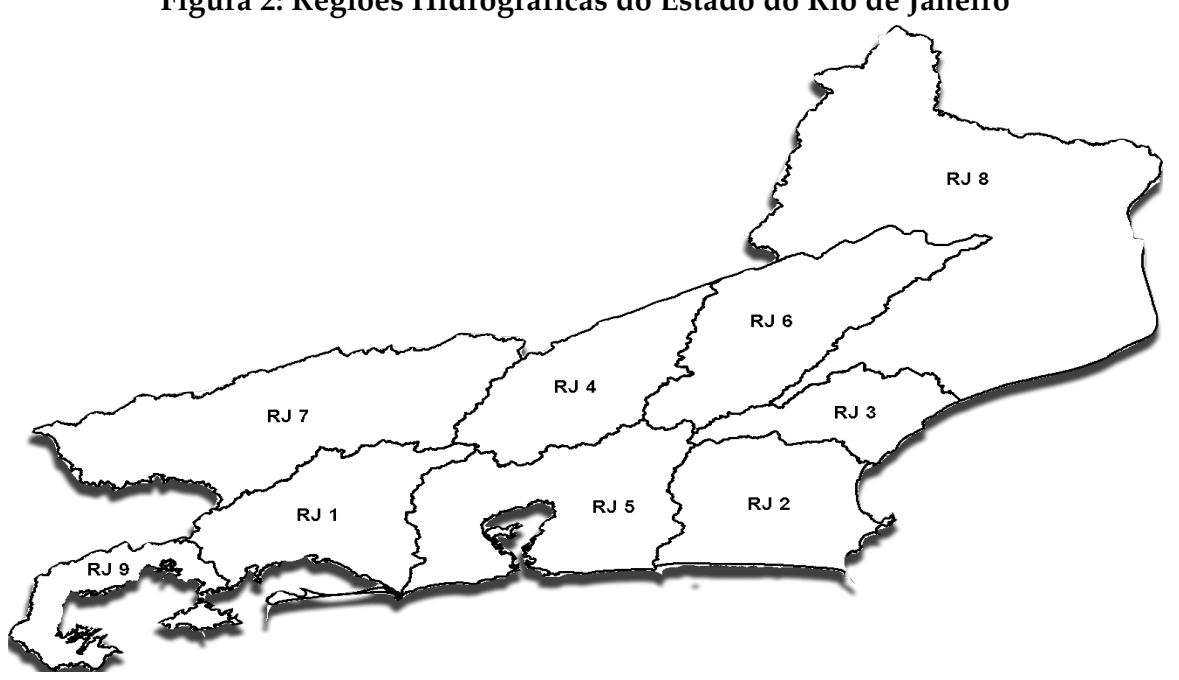

Fonte: http://www.cbh.gov.br/DataGrid/GridRio.aspx

\footnotetext{
${ }^{9}$ Ver art. 39 da Lei 9.433 de 1997, onde considera os "Comitês de Bacia Hidrográfica são compostos por representantes: I - da União; II - dos Estados e do Distrito Federal cujos territórios se situem, ainda que parcialmente, em suas respectivas áreas de atuação; III - dos Municípios situados, no todo ou em parte, em sua área de atuação; IV dos usuários das águas de sua área de atuação; V - das entidades civis de recursos hídricos com atuação comprovada na bacia”.
} 
Tabela 4: Comitês das Bacias Hidrográficas do Estado do Rio de Janeiro

\begin{tabular}{c|l|c|c|c|c|c}
\hline Código & \multicolumn{1}{|c|}{ Comitê } & $\begin{array}{c}\text { Instrumento } \\
\text { de Criação }\end{array}$ & $\begin{array}{c}\text { Data de } \\
\text { Criação }\end{array}$ & $\begin{array}{c}\text { Área Aproximada } \\
\text { (em km2) }\end{array}$ & $\begin{array}{c}\text { População } \\
\text { (hab.) }\end{array}$ & $\begin{array}{c}\text { Número de } \\
\text { Municípios }\end{array}$ \\
\hline RJ1 & CBH do Rio Guandu & Dec. 31.178 & $03 / 04 / 2002$ & 3.800 & 990.000 & 15 \\
\hline RJ2 & CBH Lagos São João & Dec. 36.733 & $08 / 12 / 2004$ & 3.800 & 520.000 & 12 \\
\hline RJ3 & CBH do Rio Macaé e das Ostras & Dec. 34.243 & $04 / 11 / 2003$ & 2.000 & 240.000 & 4 \\
\hline RJ4 & CBH do Rio Piabanha & Dec. 38.235 & $14 / 09 / 2005$ & 3.400 & 540.000 & 10 \\
\hline RJ5 & CBH do Leste da Baia de Guanabara & Dec. 38.260 & $08 / 12 / 2004$ & 4.800 & 11.200 .000 & 17 \\
\hline RJ6 & CBH Rio Dois Rios & Dec. 41.472 & $11 / 09 / 2008$ & 4.800 & 340.000 & 11 \\
\hline RJ7 & CBH Médio Paraíba do Sul & Dec. 41.475 & $11 / 09 / 2008$ & 6.600 & 1.020 .000 & 19 \\
\hline RJ8 & CBH Baixo Paraíba do Sul & Dec. 41.720 & $03 / 03 / 2009$ & 11.300 & 810.000 & 22 \\
\hline RJ9 & CBH da Baía da Ilha Grande & Dec. 43.226 & $07 / 10 / 2011$ & 1.750 & 210.000 & 3 \\
\hline
\end{tabular}

Fonte: http://www.cbh.gov.br/DataGrid/GridRio.aspx

De acordo com o Instituto Estadual do Ambiente (INEA), o estado do Rio de Janeiro tem nove bacias hidrográficas. No entanto, para este artigo somente serão consideradas três bacias hidrográficas, que compõem o campo de pesquisa do PEA Pescarte. A tabela 5 indica as bacias que abrangem os municípios atendidos pelo projeto. A tabela 5 evidencia os municípios e os respectivos comitês de bacia a que pertencem. A maioria dos municípios selecionados compõem o comitê de bacia do Baixo Paraíba do Sul.

Tabela 5: Municípios abrangidos pelo PEA Pescarte e os respetivos Comitês de Bacias Hidrográficas

\begin{tabular}{c|c|c}
\hline $\begin{array}{c}\text { Comitê Baixo Paraíba do } \\
\text { Sul }^{\mathbf{1 0}}\end{array}$ & $\begin{array}{c}\text { Comitê Macaé e das } \\
\text { Ostras }^{11}\end{array}$ & Comitê Lagos São João $^{\mathbf{1 2}}$ \\
\hline Campos dos Goytacazes & Macaé & Arraial do Cabo \\
\hline Quissamã & - & Cabo Frio \\
\hline São Francisco de Itabapoana & - & - \\
\hline São João da Barra & - & - \\
\hline
\end{tabular}

\footnotetext{
${ }^{10}$ O Comitê da Bacia Hidrográfica do Baixo Paraíba do Sul é composto pelos municípios: Quissamã, Natividade, São João da Barra, Cambuci, Itaperuna, São José de Ubá, Italva, Santo Antônio de Pádua, Cardoso Moreira, Aperibé, Miracema, Varre-Sai, São Francisco do Itabapoana, Porciúncula e Laje do Muriaé, assim como, parcialmente, os municípios de Trajano de Morais, Conceição de Macabu, Carapebus, Campos dos Goytacazes, São Fidélis, e Santa Maria Madalena.

${ }^{11}$ O Comitê da Bacia Hidrográfica Macaé e Rio das Ostras é composto pelos municípios: Carapebus, Casimiro de Abreu, Conceição de Macabú, Macaé, Nova Friburgo e Rio das Ostras.

${ }^{12}$ O Comitê da Bacia Hidrográfica Lagos de São João é composto pelos municípios: Saquarema, Araruama, Iguaba Grande, São Pedro da Aldeia, Arraial do Cabo, Cabo Frio, Armação de Búzios e Silva Jardim.
} 
A política nacional de recursos hídricos define a gestão descentralizada e estabelece que a participação pública paritária dos três segmentos da sociedade nas decisões relativas à água, inclusive no que concerne à cobrança pelo uso.

Entretanto, a título de ilustração, de acordo com Eugênia Totti (2008), na bacia do rio Paraíba do Sul, a participação destinada ao segmento dos usuários, representado [na bacia] por aqueles que utilizam a água estritamente para fins econômicos, acaba tendo uma capacidade maior de influir no resultado das plenárias realizadas no âmbito do comitê de bacia hidrográfica.

A próxima seção faz um breve relato do primeiro passo do PEA Pescarte no campo, a partir das reuniões de apresentação do projeto às lideranças e comunidades de pescadores artesanais.

\section{A falência hídrica e seus efeitos pela fala dos pescadores artesanais: as reuniões de pauta aberta e os grupos focais do PEA Pescarte}

As informações tratadas nesta seção referem-se aos resultados das reuniões de apresentação do Projeto PEA Pescarte aos pescadores artesanais e familiares, realizadas ao longo de 2014 e 2015. Os encontros foram estabelecidos para apresentar o projeto aos pescadores e ouvir o que tinham a dizer sobre a pesca e a vida de pescadores(as). No caso em questão foram consideradas as falas que relatavam as dificuldades dos pescadores artesanais em decorrência da degradação dos rios, lagos e lagoas da região e os impactos deste problema para a atividade da pesca. Ou seja, a água vista como um "fator de produção" essencial para essa classe de trabalhadores.

As reuniões foram conduzidas pelos pesquisadores do PEA Pescarte e contaram com as principais lideranças identificadas durante a aplicação do questionário de forma censitária do PEA Pescarte; além de instituições de representação dos interesses dos pescadores. As instituições presentes eram de três tipos: (1) colônias ${ }^{13}$; (2) associações formais ${ }^{14} \mathrm{e}(3)$ associações informais de pescadores. As informações realçadas nesta etapa do artigo, toma por base às descrições contidas nas reuniões com os pescadores.

\footnotetext{
${ }^{13}$ As colônias possuem o status de representante formal dos pescadores, assumindo o papel de sindicato dos pescadores.

${ }^{14}$ As associações registradas que assumem uma bandeira de luta de alguma classe de pescadores que não se vê representado pela colônia. Normalmente orientados por um domínio territorial marcado pela presença da água.
} 
As contradições dos dois públicos (pescadores marítimos e de águas interiores) foi claramente perceptível. Enquanto para os pescadores marítimos ainda há uma pesca de volume alto, e não há risco de uma falência hídrica, aos pescadores de águas de continentais cabe a recorrências de períodos de estiagem; ocupação de áreas de desova; superexploração dos recursos hídricos; invasão de espécies exóticas; levando à diminuição crônica de espécies importantes comercialmente. Para o desenvolvimento deste artigo serão analisadas as falas e opiniões dos pescadores de águas de interiores, em que pese a propalada "falência hídrica" dos rios, lagos e lagoas.

Deste ponto em diante nos valeremos das falas e opiniões dos pescadores artesanais coletadas nas reuniões de pauta aberta, realizadas entre o segundo semestre de 2014 e primeiro de 2015. Procurou-se destacar os elementos que poderiam ajudar no entendimento da relevância das águas enquanto meio de produção e subsistência para este setor da economia. Foram reuniões onde a equipe de campo do PEA Pescarte apenas acompanhou e mediou as discussões, que em boa medida, foram temas levantados pelos participantes. E, para a construção deste artigo foram pinçados os temas que abordavam questões relativas ao uso da água enquanto um bem essencial para a sobrevivência e sustento dos pescadores.

O relato parte de um problema recorrente em todas as falas, nas reuniões e grupos focais com os pescadores artesanais, que é a questão da falência hídrica dos rios, lagos e lagoas da região Norte Fluminense, no estado do Rio de Janeiro. O que difere é o tom das falas sobre o problema.

De início vale ressaltar a fala de um pescador de Campos dos Goytacazes, pertencente ao Comitê de Bacia do Baixo Paraíba, em que é categórico ao dizer que, "os pescadores querem é justiça", e que na atualidade, "eles sobrevivem de lagoas, pois o Rio Paraíba não tem como pescar mais. Hoje não tem mais peixe [ele culpa as usinas de álcool e açúcar, além de empresas que produzem e usam insumos químicos e que já foram responsáveis por desastres ambientais de grande vulto ${ }^{15}$. Segundo ele a "poluição do rio Paraíba é o principal fator pela falta de peixes na região".

A região de Campos dos Goytacazes é recortada por várias lagoas e, uma das principais é a Lagoa de Cima, que abriga uma população pesqueira tradicional que vem sendo vítima da expansão imobiliária produzida pela atração de um contingente populacional para trabalhar nas indústrias ligadas ao setor de petróleo e gás, e que tem buscado terras baratas para produzirem seus assentamentos, afetando de forma

\footnotetext{
${ }^{15}$ Acidente ocorrido na confluência do Rio Paraíba do Sul com o Paraibuna, em 1982, que derramou resíduos de metais pesados oriundos da Companhia Paraibuna de Metais e, em 2003 o rompimento de um reservatório de substâncias químicas da Indústria Cataguases de Papel (Alves; Silva e Bernstein, 2013).
} 
importante as condições de balneabilidade e pescosidade das águas. Tal condição pode ser retratada na fala de um dos líderes dos pescadores dessa lagoa, ao dizer que "existe uma revolta muito grande [com as empresas e o poder público] por parte dos comunitários da Lagoa de Cima"; que "eles não precisam de dinheiro e sim de peixe". E reforça que "os impactos que estão sendo causados geram falta de peixe".

Em outra reunião, um pescador disse que "a Lagoa do Campelo está morrendo junto com os pescadores" e que já falaram com o governo local. Que para os pescadores o "melhor projeto seria abrir as comportas para colocar água e peixe na lagoa e que não estão fazendo isso é para aumentar a área de pasto dos fazendeiros" e termina dizendo que "que, agora, nós vamos conseguir esperar mais tempos sem água". Outro pescador diz que "não adianta, que hoje o Rio Paraíba está a poucos quilômetros de distância da lagoa, mas nós não temos a autorização para abrir a água [comportas] e, eles não entendem que se precisa da água para ter o pescado". Outro pescador, um pouco mais contundente, disse que os pescadores "não vão aguentar esperar pois o problema é pra hoje e que a Lagoa do Campelo não tem peixe e que [...] o pescador não estudou e que trabalha nas madrugadas e, não têm qualificação pra arrumar um novo emprego". Ele considera que,

(...) os pescadores de águas de interiores precisam de água e peixe, mas precisam saber se articular para que saibam vender o pescado e que o problema ambiental de falta d'agua é um problema sério, o Rio Paraíba está sem água por falta de planejamento de pessoas que ocupam postos de autoridade e que não estão nem aí ${ }^{16}$.

A fala se estendeu sobre a situação do berçário de peixes que alimenta o rio Paraíba. Segundo relato, com seca e poluição estes berçários estão desaparecendo. "Precisamos de alevinos e água, mas o rio Paraíba está morto. Vimos na mídia que há $\mathrm{R} \$ 38$ milhões para recuperar o rio, mas não vimos esse dinheiro". Além do mais, foi dito que "seria necessário estabelecer uma cota para a lagoa, pois quem manda nas comportas são os fazendeiros, e estes estão fazendo o esvaziamento das lagoas para transformar em pasto ou agricultura". Essa fala relaciona diretamente a opção dos órgãos ambientais em atenderem primeiramente às necessidades dos produtores rurais que impedem que as comportas que ligam a foz do rio Paraíba do Sul aos leitos das lagoas sejam abertas,

\footnotetext{
${ }^{16}$ Reunião de pauta aberta do PEA Pescarte, em Campos dos Goytacazes, com os pescadores da Lago do Campelo, em 07 de novembro de 2014 .
} 
impedindo o seu enchimento completo para que as áreas não ocupadas pelas águas sejam cobertas por pastagem para o gado.

Tal situação interfere na pesca de água doce, uma vez que uma fração das águas reservadas nas lagoas são desviadas para irrigação da agricultura, o que inclui parte das plantações de cana-de-açúcar cultivada na região, com cerca de 50.000 hectares plantados. Deste modo, afeta de forma direta as bacias de desovas. Existe também a "pesca predatória e pesca no período de defeso". Ou seja, passa a ser mais um problema a ser enfrentado pelos pescadores que "terão que enfrentar [as dificuldades] para frente referente à falta de água e peixe ${ }^{17 "}$.

A tabela 6 traz a informação coletada junto ao universo de pescadores artesanais entrevistados pelos pesquisadores do Projeto Pescarte, sobre o recebimento do Seguro Defeso. Trata-se de um instrumento de política pública específico para os pescadores cadastrados pelas Colônias de Pesca, para o período em que a pesca é proibida. Essa proibição ocorre de acordo com cada espécie de pescado, em função da desova e recrutamento de novos indivíduos. Durante este tempo o pescador fica proibido de capturar aquela espécie e, portanto, funciona como uma espécie de "seguro desemprego", até que seja liberada a pesca. Pouco mais da metade dos respondentes disseram receber o Seguro Defeso. Mas, chama atenção a outra metade, que não recebe esse subsídio, o que os coloca em situação de maior vulnerabilidade econômica e social.

Tabela 6 - O(a) Sr.(Sra.) recebe seguro defeso?

\begin{tabular}{llrrrr}
\hline \hline & & & $\begin{array}{c}\text { Porcentagem } \\
\text { válida }\end{array}$ & $\begin{array}{r}\text { Porcentagem } \\
\text { acumulativa }\end{array}$ \\
\hline Válido & Sim & 1.855 & 42,8 & 52,5 & 52,5 \\
& Não & 1.676 & 38,7 & 47,5 & 100,0 \\
& Total & 3.531 & 81,5 & 100,0 & \\
\hline \multirow{2}{*}{ Ausente } & Não respondeu & 795 & 18,4 & & \\
& Não sabe & 5 &, 1 & & \\
& Total & 800 & 18,5 & & \\
\hline Total & & 4.331 & 100,0 & & \\
\hline \hline
\end{tabular}

Fonte: Questionário PEA Pescarte, 2015.

Esse problema também é recorrente nos municípios pertencentes ao Comité da Região do Lagos e do Rio São João. Especificamente, os pescadores da Lagoa de Araruama, afirmam que a laguna "está perdendo a sua salinidade e com isso muitas espécies estão

\footnotetext{
${ }^{17}$ Reunião de pauta aberta do PEA Pescarte em Campos dos Goytacazes, nas comunidades de Parque dos Prazeres e Vigário, em 10 de novembro de 2014.
} 
abandonando a lagoa, afetando assim a pesca na região". E como um complicador para os pescadores que atuam na lagoa, foi dito também, "que há um grande despejo de esgoto sem tratamento na lagoa"18.

As informações se repetem nos grupos focais realizados pela equipe do PEA Pescarte. Segundo um pescador de Arraial do Cabo, também da mesma bacia da região dos lagos, "o principal problema enfrentado pela pesca, para o pescador da lagoa, é a poluição, que afeta as espécies de peixes naquele ecossistema, porque retira o oxigênio da água. Este fato está reduzindo a quantidade de camarão pescado na lagoa e adoecendo as tainhas". Relatou ainda, "que grandes empresas de pesca descartam quilos de peixes no canal, aumentando a poluição da lagoa, pois quando a maré sobe os peixes mortos vão para o fundo da lagoa". Isso ocorre, segundo o relato do pescador, pelo fato de que "as empresas capturam peixes pequenos e separam os grandes que são vendidos e os pequenos que são descartados no canal". Outro pescador relatou que "estas empresas dominam o cais", retirando espaço de trabalho dos pescadores artesanais. Da mesma forma, apontou-se que "a falta de pescado é decorrente da poluição e dos barcos de petróleo". A tabela 7 , mostra que $48 \%$ dos respondentes disseram que a indústria de petróleo e gás interfere nas suas atividades laborais na pesca, contra $52 \%$ que afirmam não haver interferência.

Tabela 7 - A atividade de petróleo influencia na atividade pesqueira?

\begin{tabular}{llrrrr}
\hline \hline & & & & $\begin{array}{c}\text { Porcentagem } \\
\text { válida }\end{array}$ & $\begin{array}{r}\text { Porcentagem } \\
\text { acumulativa }\end{array}$ \\
\hline Válido & Não & 1.618 & 37,4 & 52,0 & 52,0 \\
& Sim & 1.492 & 34,4 & 48,0 & 100,0 \\
& Total & 3.110 & 71,8 & 100,0 & \\
\hline Ausente & Não respondeu & 1.054 & 24,3 & & \\
& Não sabe & 167 & 3,9 & & \\
& Total & 1.221 & 28,2 & & \\
\hline Total & & 4.331 & 100,0 & & \\
\hline \hline
\end{tabular}

Fonte: Questionário PEA Pescarte, 2015.

Em relação a este tema, de uma forma mais direta, foi perguntado aos pescadores se "a atividade de petróleo influência na atividade pesqueira?". Em boa medida, foi apontado pelos entrevistados que essa indústria "trouxe mais prejuízos que benefícios", com um

\footnotetext{
${ }^{18}$ Reunião de pauta aberta do PEA Pescarte em Arraial do Cabo, com a comunidade do Figueira, 17 de novembro de 2014.
} 
percentual válido de 52,8\%, e que "trouxe somente prejuízo", com $31,6 \%$ das respostas válidas, em um universo de 1.556 entrevistas. O equivalente a 31,2\% dos respondentes disse que a indústria de petróleo e gás trouxe como benefícios para a região, "mais empregos", seguida da "formação de arrecifes nas plataformas", com 24,07\%, e igualmente apontadas, os "programas de compensação" e os "royalties para os municípios", com 14,3\%. As demais respostas não tiveram significância.

Tais questões, segundo informado no grupo focal, foram levadas à Colônia de Pescadores do município e que a posição assumida pelas colônias em favor dos pescadores nunca foi atendida. Ou seja, de acordo com os relatos, já foi cobrado a fiscalização aos órgãos competentes, em função destes problemas, que envolvem a qualidade da água para a pesca de lagoa e rios, mas que "ela [a fiscalização] não funciona"19 , fiscalização essa que está dividida entre o órgão federal (IBAMA) e o órgão estadual (INEA), respectivamente responsáveis pelas ações de fiscalização marítima e de águas de interiores.

A tabela 8 evidencia os achados de uma questão recorrente em praticamente todas as falas, tanto em reuniões de pauta aberta, quanto nos grupos focais, que é a fiscalização da atividade de pesca. O equivalente a 62,1\%, disse que "há sim, fiscalização", mas, que essa fiscalização aponta suas ações somente para os pequenos pescadores, deixando com que as traineiras (barcos de grande porte) atuem sem limites.

Tabela 8 - Nesta localidade, há fiscalização da atividade de pesca?

\begin{tabular}{llrrrr}
\hline \hline & & & \multicolumn{2}{c}{$\begin{array}{c}\text { Porcentagem } \\
\text { válida }\end{array}$} & $\begin{array}{r}\text { Porcentagem } \\
\text { acumulativa }\end{array}$ \\
\hline Válido & Sim & 2.011 & 46,4 & 62,1 & 62,1 \\
& Não & 1.226 & 28,3 & 37,9 & 100,0 \\
& Total & 3.237 & 74,7 & 100,0 & \\
\hline Ausente & Não respondeu & 1.045 & 24,1 & & \\
& Não sabe & 49 & 1,1 & & \\
& Total & 1.094 & 25,3 & & \\
\hline Total & & 4.331 & 100,0 & & \\
\hline \hline
\end{tabular}

Fonte: Questionário PEA Pescarte, 2015.

Tais questões também aparecem em outros grupos focais, como em Cabo Frio, onde um pescador relata que "o derramamento de óleo na água pelas grandes indústrias leva a morte dos peixes - há um forte mau cheiro vindo de algumas lagoas, entretanto, na análise da água feita pelos fiscalizadores não foi encontrado nenhum problema". Para o pescador,

\footnotetext{
${ }^{19}$ Grupo focal realizado pelo PEA Pescarte com os pescadores de Arraial do Cabo, em 09 de abril de 2015.
} 
é necessária uma maior fiscalização. Isso faz com que o pescador duvide da confiabilidade do exame realizado, ao se posicionar com "certeza que há algum problema na água, e isso fica claro com a mortandade dos peixes e com a grande dificuldade que vem enfrentando na pesca de camarão". No mesmo grupo relata que "os problemas da lagoa começaram a surgir depois que as comportas foram fechadas", impedindo a renovação das águas das lagoas.

O pescador afirma que a "água da lagoa está verde igual água de esgoto, e que não consegue mais pescar naquela localidade, uma vez que não há mais peixes" ${ }^{20}$. Sobre este aspecto uma pescadora salienta que "existe a necessidade desta conscientização de todos, os próprios moradores poluem os rios e depois contestam com o governo quando há enchentes e problemas com rios e vias fluviais". E o que "era chamado de 'águas maravilhosas', que hoje não é mais usado por motivo de poluição". Mas existe também o problema do lixo produzido pela indústria do turismo. Este problema pode ser evidenciado na fala de um pescador de Cabo Frio ao dizer que: "eu retirei $250 \mathrm{~kg}$ de lixo da praia de Carapebus e joguei no lixo do mercado de peixes. Não fui eu que consumi esse lixo, mas foram os banhistas que levaram"21.

Os relatos apresentados nos grupos focais realizados em Campos dos Goytacazes, apontaram outros tipos de indignações, por parte dos pescadores. Parte considerável das reclamações apontaram para os problemas com a associação de moradores da região. Segundo foi apontado, "não existem fiscalizações rígidas, no que se refere aos tipos de redes utilizadas para a pesca, o que ocasiona a escassez de peixes, devido ao tamanho de malha da rede que retira da lagoa, também, peixes em período de reprodução". Neste sentido, "a falta de fiscalização dos instrumentos utilizados para a pesca serve de estímulo para pesca ilegal". Aqui vale trazer os resultados do Censo Pescarte sobre "quais órgãos realizam a fiscalização". De um conjunto grande de instituições apontadas pelos entrevistados destacam-se o IBAMA, com 36,3\% de apontamento, seguido da Capitania dos Portos, com $15,1 \%$ e, na sequência, pelo INEA, com 10,9\%.

Outro problema é "a falta de água atrapalha a procriação dos peixes, o que dificulta a pesca". Ao final da sua fala o pescador disse que "ama a pesca, porém, deixa claro que não quer que o filho siga o mesmo caminho" 22 . Este foi um ponto que foi abordado em praticamente todos os grupos focais realizados nos municípios pelo PEA Pescarte. A tabela 9 traz um dado que chama atenção, que é o percentual elevado, de

\footnotetext{
${ }^{20}$ Grupo focal realizado pelo PEA Pescarte com os pescadores de Cabo Frio, em 08 de abril de 2015.

${ }^{21}$ Grupo focal realizado pelo PEA Pescarte com os pescadores de Cabo Frio, em 18 de março de 2015.

${ }^{22}$ Grupo focal realizado pelo PEA Pescarte com os pescadores de Campos dos Goytacazes, em 10 de março de 2015.
} 
$85,2 \%$, dos respondentes, que não gostariam que seus filhos trabalhassem na pesca. Tais questões colocam um alerta em relação aos problemas enfrentados pelos pescadores artesanais, a questão das águas é um destes problemas, que pinta um cenário preocupante para a pesca artesanal.

Tabela 9 - O(a) Sr.(Sra.) gostaria que seus(uas) filhos (as) trabalhassem na pesca?

\begin{tabular}{llrrrr}
\hline \hline & & & & Porcentagem & Porcentagem \\
válida & acumulativa \\
\hline Válido & Não & 2.754 & 63,6 & 85,1 & 85,1 \\
& Sim & 484 & 11,2 & 14,9 & 100,0 \\
& Total & 3.238 & 74,8 & 100,0 & \\
\hline \multirow{2}{*}{ Ausente } & Não respondeu & 1.041 & 24,0 & & \\
& Não sabe & 52 & 1,2 & & \\
& Total & 1.093 & 25,2 & & \\
\hline Total & & 4.331 & 100,0 & & \\
\hline \hline
\end{tabular}

Fonte: Questionário PEA Pescarte, 2015.

Nos grupos focais realizados em Quissamã a pesca de água doce foi descrita como "uma situação precária, devido ao assoreamento e consequente diminuição do volume de água nas lagoas". À falta de água nas lagoas foi atribuída em parte, por um pescador, ao "fechamento da comporta da barra que não permite a entrada de água nas lagoas, e a seca que assolou as lagoas ocorre o avanço da água do mar e prejudica a pesca". Diz ainda, que “a Lagoa Feia está em condições precárias, quase seca. Os fazendeiros prejudicam a fluência das águas na lagoa ${ }^{23 "}$.

Foi discutido também sobre a pesca predatória, que apresentou-se como um "grande complicador, pois muitos pescadores que não são da região usam 'rede de boia' e pegam qualquer espécie e principalmente peixes pequenos que são dispensados nas margens gerando um desperdício e desaparecimento de peixes maiores". Nesse ponto foi destacada a falta de fiscalização por parte dos órgãos competentes no campo e a falta de consciência do pescador, pois ao praticarem a pesca irregular prejudicam as pescas maiores, visto que pescam fora de época e prejudicam o ciclo natural ${ }^{24}$.

\footnotetext{
${ }^{23}$ Grupo focal realizado pelo PEA Pescarte com os pescadores de Barra do Furado, em Quissamã, em 10 de março de 2015.

${ }^{24}$ Grupo focal realizado pelo PEA Pescarte com os pescadores de Barra do Furado, em Quissamã, em 18 de março de 2015.
} 
Em São Francisco do Itabapoana o quadro se repete, em relação às queixas dos pescadores no que se refere aos problemas das águas. Nas falas dos pescadores que participaram dos grupos focais, estes afirmam que "a barra hoje não tem mais profundidade para o rio correr e os peixes entrarem". O assoreamento da barra gera um banco de areia que retira os alimentos dos peixes. Um pescador relatou que "para fazer alguns trajetos de barco é necessário esperar que a água do rio suba". Soma-se a isso "a poluição produzida pelas empresas, de modo que isso não afeta apenas ao pescador, mas também ao meio ambiente e a população da cidade que precisa do peixe para se alimentar".

Ainda nessa mesma linha uma pescadora apontou que em "sua localidade tem quatro qualidades de siri, que é mais rentável, mas como a água do rio salgou, o siri desapareceu. Os caranguejos estão morrendo porque não estão acostumados a viver na água salgada". Diante deste quadro foi dito que "os pescadores têm procurado uma função melhor, mais lucrativa e diz que tem que se virar como ajudante de pedreiro para sobreviver". Na sequência, um pescador começa sua fala dizendo que,

“(...) o rio acabou e que hoje só se vê o raso. Antes a lama era difícil de tirar da rede, mais a gente pegava peixe. Hoje tem limo e não pega peixe. Não há peso d'água para a rede andar. As tainhas e as tainhotas não têm onde se esconder. O rio secou e o mar avançou e está salgando a água até lá em cima. Traíra, tilápia, acará, que se tinha muito na Barra, sumiu."

Uma pescadora ressaltou que "as barragens de hidroelétricas instaladas as margens dos rios, fazendo a água do mar avançar cada vez mais para os manguezais". Afirma que "esse ano, caranguejo que eu peguei, tava sal puro, já perdi muito caranguejo [por conta da hidrelétrica] ${ }^{25}$ ", apontando para outro problema enfrentado pelos pescadores, que é a construção de barragens hidrelétricas que não os reconhece como sendo atingidos pelo represamento das águas.

Nesta mesma linha segue a fala de um outro pescador, de Gargaú, que disse ser "nascido e criado na pesca no qual começou a pescar desde seus oito anos de idade no Rio Paraíba do Sul, onde pescava toda espécie de peixe e lagostas". Segundo ele que "tudo isso se acabou". Mas condiciona que o "problema do rio é a seca, pois hoje em dia não se encontra, no rio, lugar profundo, e cheio de limo". Além disso, contou que "o mar está

\footnotetext{
${ }^{25}$ Grupo focal realizado pelo PEA Pescarte, em São Francisco do Itabapoana, em 05 de dezembro de 2014.
} 
invadindo o rio deixando assim salinizada, dificultando a encontrar peixes de água doce ${ }^{26}$, tudo isso, devido a falta d'água por causa dessas hidrelétricas".

A tabela 10 destaca a preocupação dos pescadores artesanais com as mudanças ocorridas nas áreas em que atuam na pesca. O percentual elevado, de respostas positivas, $78,0 \%$, chama atenção para os efeitos decorrentes da poluição, a presença da indústria de petróleo e gás, a indústria do turismo, as represas hidrelétricas, além de outras questões que corroboram com as justificativas e preocupação junto aos pescadores respondentes que aponta para um verdadeiro desastre ambiental, lento e silencioso.

Tabela 10 - O (a) Sr. (Sra.) tem percebido, nos últimos anos, alguma alteração na sua área de pesca?

\begin{tabular}{llrrrr}
\hline \hline & & & $\begin{array}{c}\text { Porcentagem } \\
\text { válida }\end{array}$ & $\begin{array}{c}\text { Porcentagem } \\
\text { acumulativa }\end{array}$ \\
\hline Válido & Sim & 2.553 & 58,9 & 77,6 & 77,6 \\
& Não & 738 & 17,0 & 22,4 & 100,0 \\
& Total & 3.291 & 76,0 & 100,0 & \\
\hline Ausente & Não respondeu & 1.003 & 23,2 & & \\
& Não sabe & 37 &, 9 & & \\
& Total & 1.040 & 24,0 & & \\
\hline Total & & 4.331 & 100,0 & & \\
\hline \hline
\end{tabular}

Fonte: Questionário PEA Pescarte, 2015.

A este percentual expressivo de indicações de percepção de mudança na área da pesca, de um total de 3.411 de respostas validadas, tem-se o equivalente a $22,1 \%$ dos respondentes afirmando que houve, no tempo, uma "diminuição do volume/quantidade de pescado", seguida da resposta relacionada ao "assoreamento/poluição" das águas e de outra resposta que se refere à "diminuição do volume/quantidade de pescado/desaparecimento de determinadas espécies".

Em São João da Barra, nos grupos focais, foi dito que "aproximadamente $90 \%$ dos pescadores não conseguem viver apenas do pescado". Um desses "motivos seria o aterramento da lagoa Guipari e outras lagoas", por parte do Porto do Açu ${ }^{27}$. Isso foi responsável pela diminuição dos peixes, pois, foi aterrado justamente a parte que era considerada como berçário da lagoa. Uma pescadora afirmou também, que "o INEA

\footnotetext{
${ }^{26}$ Grupo focal realizado pelo PEA Pescarte em São Francisco do Itabapoana, em 03 de março de 2015.

${ }^{27}$ Empreendimento portuário localizado no município de São João da Barra e responsável por impactos no ambiente marinho. O processo de licenciamento do Porto do Açu ficou a cargo do INEA.
} 
proíbe a limpeza das lagoas, e que o avanço do mato acabava com algumas espécies de plantas que os peixes gostam de comer". Disse ainda que "depois que foi criado o parque da lagoa, ocorreu uma escassez de peixes, porque antes acontecia troca entre os peixes, quando não abre a barra, não há troca entre os peixes".

As falas apontaram para os impactos da construção do Porto de Açú, que mudou a realidade da população e, inclusive, a afirmação, confirmada por estudo científicos ${ }^{28}$, que “o canal gerou a salinização das águas, atrapalhando os pequenos agricultores da região, $\mathrm{e}$ resultando na perda de suas lavouras, sendo preocupante, já que é a única atividade desenvolvida por estes no período do defeso". Uma pescadora aponta um outro problema enfrentado pelos pescadores artesanais de água doce do município, que refere-se ao "assoreamento das margens do rio e lagoas, e o avanço do mar".

Foram levantadas questões como os embates de opiniões divergentes quanto às a normas ambientais, e até mesmo episódios violentos que ocorreram em outras regiões, como na Chatuba, entre pescadores e instituições de fiscalização como o IBAMA e o INEA. Abordou-se também, a problemática ambiental sobre "o fechamento da barragem na região de São João da Barra", causador de discordância dos pescadores e essas organizações de cunho ambiental e entidades municipais sobre períodos e épocas apropriadas para tal ação do fechamento da barragem. A tabela 11 aponta que 30,4\% dos entrevistados consideram que há conflito com os órgãos de fiscalização.

Tabela 11 - Existem conflitos entre os pescadores e órgãos fiscalizadores?

\begin{tabular}{llrrrr}
\hline \hline & & & $\begin{array}{c}\text { Porcentagem } \\
\text { válida }\end{array}$ & $\begin{array}{r}\text { Porcentagem } \\
\text { acumulativa }\end{array}$ \\
\hline Válido & Não & 2.090 & 48,3 & 69,6 & 69,6 \\
& Sim & 911 & 21,0 & 30,4 & 100,0 \\
& Total & 3.001 & 69,3 & 100,0 & \\
\hline Ausente & Não respondeu & 1.245 & 28,7 & & \\
& Não sabe & 85 & 2,0 & & \\
& Total & 1.330 & 30,7 & & \\
\hline Total & & 4.331 & 100,0 & & \\
\hline \hline
\end{tabular}

Fonte: Questionário PEA Pescarte, 2015.

Nesse ponto foi endossando pelos pescadores, que "o problema da pesca na região são os acessos fechados, como exemplo a barra da lagoa". Neste sentido, segundo os relatos, "os

\footnotetext{
${ }^{28}$ Estudos do Laboratório de Ciências Ambientais (LCA) da UENF, realizados entre outubro e dezembro de 2012 , apontaram a salinização das águas distribuídas para o consumo humano no município e também para irrigação de lavouras.
} 
pescadores de lagoa são prejudicados por essa interferência que afeta os pontos onde a piscosidade é mais acentuada".

Por fim, um pescador, dos mais velhos entre aqueles que participaram dos grupos focais, ao concordar com as demais opiniões, reforçou ainda ao dizer que "a lagoa acabou e a vida dos pescadores também." 29 .

\section{Considerações finais}

Este artigo teve o objetivo analisar a essencialidade das águas, não em seu aspecto relacionado ao consumo humano, mas para as condições de trabalho e subsistência econômica das famílias de pescadores artesanais da Bacia de Campos. O ponto aqui é compreender a importância deste "fator de produção", sob a ótica de quem trabalha e depende das águas. Em especial os pescadores de águas de interiores que fazem uso do sistema de bacias hidrográficas. Sob a ótica destes trabalhadores a preservação ambiental é uma condição para a sobrevivência desta profissão.

A questão que se verificou ao logo da pesquisa é que o mecanismo formal de participação social em relação a essa temática, via comitês de bacia, não tem se mostrado um caminho acessível a estes trabalhadores, que vivem desse recurso de produção. Assim, as demandas e apontamentos dos pescadores artesanais não ecoam nestes mecanismos formais de participação.

No que concerne as inserções no campo temos verificado que as condições impostas para o desenvolvimento dos trabalhos relacionados à pesca artesanal têm se tornado dramática e levado a que muitos pecadores abandonem seu ofício. Com o agravante de que não querem que seus filhos sigam essa profissão. O que ascende um sinal amarelo no que se refere à continuidade de uma atividade secular, seja nessa região do estado do Rio de Janeiro, como em qualquer outra localidade do país.

O descaso com a degradação dos rios, lagos e lagoas só faz aumentar esse "desânimo quanto à pesca artesanal", tão aventado por estes trabalhadores em todas as conversas que fizeram parte da pesquisa. Deste modo, as informações aqui coletadas têm evidenciado essa preocupação e aponta para a necessidade de que ações junto aos órgãos públicos sejam encaminhadas sob pena de vermos essa tradicional comunidade desaparecer.

\footnotetext{
${ }^{29}$ Grupo focal realizado pelo PEA Pescarte em São João da Barra, em 25 de março de 2015.
} 


\section{Referências bibliográficas}

Alves, Verônica B. Souza; Silva, Jonas E. da; e Bernstein, Any. Impactos do acidente na Indústria de Papel e Celulose Cataguases, no Rio Paraíba do Sul. In: Meio Ambiente. Educação Pública. $\quad$ CECIERJ, 2013. Disponível em http://www.educacaopublica.rj.gov.br/biblioteca/meioambiente/0040.html, Consultado em 18/junho/2015.

Campos, M.M.; Timoteo, G.M.; Silva, T. Augusto da. Responsabilidade Social Offshore: ausência do Estado, incentivos privados e ressonância da fala dos pescadores artesanais. In: WATERLAT-GOBACIT Network Working Papers - Inequality, injustice, and social change: the fate of artisanal fishing communities in Latin America. V. 2, 2015. pp. 154-172.

CBH: Comitês de Bacias Hidrográficas - Rio de Janeiro. Disponível em Fonte: http://www.cbh.gov.br/DataGrid/GridRio.aspx. Acesso em 18/junho/2015.

CENSO PEA PESCARTE. Projeto de Mitigação Ambiental PETROBRAS/IBAMA/UENF. Campos dos Goytacazes, 2015.

Denhez, F. Tout savoir sur l'eau - Guide visuel. Éditions Marcel Didier. Canada. 2013.

Giddens, A. A política da mudança climática. Rio de Janeiro: Zahar, 2010.

IBAMA, Nota Técnica CGPEG/DILIC/IBAMA, no 2010. http://www.ibama.gov.br/servicos/nota-tecnica-cgpeg/dilic/ibama-n-01/10, Consultado em 09/dezembro/2016.

ONU. Declaração do Rio sobre Meio Ambiente e Desenvolvimento. Princípio 10. Disponível em http://www.onu.org.br/rio20/img/2012/01/rio92.pdf. Consultado em 18/junho/2015.

PESCARTE. Plano de Trabalho do Projeto PESCARTE - EA. Linha de Ação A: Organização Comunitária para Participação na Gestão Ambiental no Âmbito do Licenciamento Ambiental. Campos dos Goytacazes, novembro de 2013.

PETROBRAS; MINERAL ENGENHARIA E MEIO AMBIENTE - EMPRESA BRASILEIRA DE PETRÓlEO. Audiência Pública do TAC (termo de ajustamento de conduta) para 
licenciamento das atividades de exploração de petróleo e gás na Bacia de Campos - TACBC, 2015.

RELATÓRIO FINAL DO DIAGNÓSTICO PARTICIPATIVO DO PEA-BC. Plano de Trabalho para continuidade do Diagnóstico Participativo da Bacia de Campos - PEA-BC. $2014 . \quad$ Disponível em: <http://peabc.ibp.org.br/arquivos/secoes/60_relatorio_pea_bc_rev.04_final.pdf $>$. Consultado em 20/outubro/2016.

GT de Assuntos Agrários - Associação dos Geógrafos Brasileiros - Seções Rio de Janeiro e Niterói link:

11.03.2013

http://www.pacs.org.br/files/2013/03/Saliniza\%C3\%A7\%C3\%A3o_das

_\%C3\%A1guas_e_do_solo_de_SJBFINAL.pdf, Consultado em 09/12/2016.

Totti, Maria Eugência. F. Gestão das águas na Bacia Hidrográfica do Rio Paraíba do Sul: governança, instituição e atores. 2008. 133f. Tese (Doutorado em Ecologia e Recursos Naturais) - UENF, Campos dos Goytacazes, RJ. 